\title{
Modernising local government by fragmentation: Lessons from the Portmore municipal experiment, Jamaica
}

Commonwealth Journal of Local Governance

Special Issue March 2010:

Commonwealth Local Government Conference

Freeport, Bahamas, May 2009

http://epress.lib.uts.edu.au/ojs/index.php/cjlg

\section{Eris D. Schoburgh ${ }^{1}$}

Department of Government,

University of the West Indies, Mona

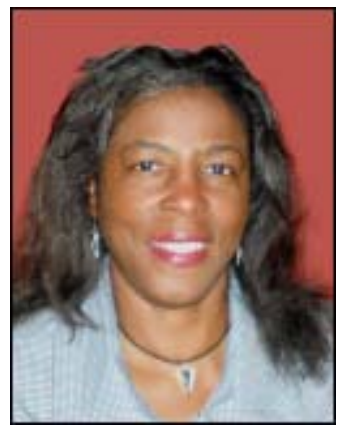

\section{Abstract}

Modernization of local government leads inevitably to the vexed question of how best to structure local authorities to meet the changing circumstances in which they operate. This is no less an issue for the Caribbean in general and Jamaica in particular, where forces such as increased suburbanization and increasing citizen demands have prompted policy shifts to respond to the changing world of local government. Re-structuring may be proposed to serve a number of key objectives: to achieve economies of scale; to assure organisational viability; or to reinvigorate local democracy. The Portmore Municipal Council in Jamaica, established under the Municipalities Act of 2003 represents fragmentation of the previous local government structure and innovates local policy and administration in two ways: through popular election of the mayor, and through new institutional arrangements designed to promote local/community selfmanagement. This paper reviews the experience of the PMC during its formative years of operation to determine the extent to which the philosophy and practice of

${ }^{1}$ I am grateful for the comments provided by the reviewers which helped me to improve this article. I also acknowledge the assistance of Dr. Allister Hinds who was a member of the team of researchers lead by me and commissioned to collect data on the PMC for the National Advisory Council on Local Government Reform in Jamaica. 
local/community self-management are in fact being institutionalised in the operations of the municipality, and to identify lessons for the broader adoption of a process of 'municipalisation'.

\section{Introduction}

Local government plays only a small role in the Jamaican system of government. In the 1980s local government was 'virtually dismantled' and its functions regionalised or subsumed by central government (CLGF, 2009). However, in recent years there has been renewed interest in decentralization and local government reform, although local authorities have yet to regain many of the functions they once had and remain heavily dependent on central government grants. There is strong central control: the Ministry of Finance sets the level of property tax, and local government staff are recruited by a national Municipal Services Commission. Currently there are 14 local authorities ranging in population from around 70,000 to over 700,000 - the capital city Kingston. The Portmore Municipal Council (PMC) is the newest of these, established in 2003 under the provisions of the newly promulgated Municipalities Act, which introduced a number of democratic reforms. PMC covers an area of recent suburban development on the western fringe of Kingston. The municipality's population was about 80,000 at the time of its creation. PMC represents an interesting experiment in 'reduction in scale' or 'fragmentation' of the administration of local government functions, given that the area was (and in some ways remains - see below) part of the much larger and longestablished Parish of St. Catherine.

Throughout the post-independence period and even up to the enactment of the Municipalities Act 2003, local government in Jamaica has been a single-tier sub-national system administered through parishes. Each parish has its own local authority, known as a Parish Council, with the exception of the parishes of Kingston and St. Andrew that are administered by the Kingston and St. Andrew Corporation (KSAC). ${ }^{2}$ While they vary considerably in area and population, the parishes are bound by the same legal provisions and occupy a similarly subordinate position in central-local relations. The Municipalities Act added a degree of complexity to the system of local government in that the creation of PMC expanded the number of local authorities to fourteen, and in the process divided an existing administrative unit, with the potential for similar fragmentation elsewhere in

2 The KSAC is a consequence of earlier reforms that sought to amalgamate local government administrative units to achieve economies of scale. 
Jamaica in years to come. The Municipalities Act 2003 does not define precisely the concept of 'municipality', but s3(3) makes it clear that their establishment is to reflect community aspirations for this new form of local government (electors and community organizations have to petition for a municipality), and should incorporate "a major urban centre that would be better served by a regime that is focused exclusively on managing the area in order to achieve sustainable and orderly development” (s3(5)). The normal minimum population for a municipality is set at 50,000. Functionally, a municipality is effectively the same as a parish, but a lesser status is implied in that firstly, a municipality remains located within a parish and its council includes those parish councillors elected to the divisions that also constitute the municipality; and secondly, through a 'protective' provision of the Municipalities Act (s3(5)(e)) that "the establishment of the municipality is not likely to have any adverse effect on the adjoining communities or the parish in general.”

A municipality is interpreted in this paper in libertarian tradition as a form of decentralization that is institutional in character. That is, a local government administrative unit, in this case a parish, is divided into smaller administrative units, effecting a shift in the locus of power from the capital town to other townships or neighbourhoods. Institutional decentralization can facilitate the development of direct democracies as decision-making is brought closer to communities. In this sense, then, the concept of 'municipalisation' may be described as the process of dismantling centralized decision-making in local government to facilitate citizens' active participation. A municipality in Jamaica is distinguishable from a parish in that it expands the democratic realm and specifically seeks to promote active citizen engagement at an appropriate scale. This is highlighted by two further provisions of the Municipalities Act that introduce a popularly elected mayor and establishment of a community-based Advisory Council. Thus although the creation of PMC did not alter the single-tier system of subnational government, PMC's interactions with the St. Catherine Parish Council (SCPC) created a number of organisational and political tensions that have been difficult to overcome and have had significant consequences for the financial state of the fledgling municipality.

This paper therefore focuses on the 'Portmore experiment' to gauge the success of creating a new municipality in terms of both administration and service delivery, and the 
extent to which the philosophy and practice of local/community self-management have been effectively institutionalised in its operations.

\section{Consolidation or fragmentation?}

As Leemans (1970:51) observes: "whenever a government wishes to fundamentally reform its system of decentralization, it tends to give primary attention to its overall structure, fitting other aspects such as allocation of powers and functions, size and boundaries of local government units into that structure.” Thus scale enlargement, scale reduction, or cooperative arrangements/partnerships represent typical policy responses in decentralization reforms.

The optimal size of local government units has for a long time seized the attention of analysts and is contested between two viewpoints: the consolidationists (or centrists) who associate enlarged local government units with economies of scale, and advocates of community government (or polycentrists) who assert that small units are more conducive to grassroots democracy. For the consolidationists, large (in population) local government units facilitate inter alia, more effective local problem-solving, greater opportunities to raise revenue without disadvantaging any group, and more optimal functioning given the increased capacity to perform a variety of tasks, as well as increased scope for effective exercise of political responsibility given the greater ability of larger units to balance local needs and resources. Those who favour fragmentation of local government units cite the incompatibilities that exist between large size and democracy, resting their claim for reduced scale on facilitation of community sovereignty and ultimately, an expanded democratic realm. Large local government units, it is argued, have a tendency to become 'super governments' that have a propensity to be insensitive to the needs of localities. For an expanded exposition of these contending positions see 'classic' works such as Madison (1941), Dahl (1967), Sharpe (1970), and Gunlicks (1981); and more contemporary writing such as Newton (1982), Magnusson (1986), Kjellberg (1995), King and Stoker (1996) and Schoburgh (2006).

In recent years public choice theory has been highlighted by those favouring smaller local government units as a supporting argument to the case for decentralized democratic governance. Public choice theorists advocate for local government fragmentation, the fundamental value of which is an increased level of political representation and participation, but also see it as conducive to economic growth. This draws on Tiebout's 
(1956) thesis that residents are similar to consumers who 'shop' between different municipalities to find the one that has the right mix of taxes and public services, and that people's ability to choose forces towns to compete against one another making these towns better able to discover and serve the needs of their citizens. At the heart of the application of public choice ideas to local government structure are quasi market values, by which public choice scholars tend to consign local governments to being merely producers of services rather than political entities. The emphasis on managerialism over democratic politics has been one of the tensions evident in the application of public choice ideas to local government reform, and has formed the basis for an emergent 'neoprogressive' perspective that hypothesizes a new case for consolidation of local government (see for example Lowery, 1999a). This challenges the public choice view that a fragmented system of local government is acceptable on the basis that individuals, given adequate information about the performance of their local authority, can exercise either a voice or exit strategy if they become dissatisfied. Neo-progressives recognize the value of adequate information, but argue that fragmentation of institutions provides greater opportunities for blurring of functional responsibilities in local government, thus weakening democratic accountability. Further, that democracy is weakened when the primary response to dissatisfaction is the exit strategy. Neo-progressives also suggest that the ability of fragmented units to respond to metropolitan-wide problems is questionable. Their thesis is that fragmented institutions preserve income inequality as a result of the disconnection between resources and needs (Hill 1974; Neiman 1976; Lowery 1999b).

What perhaps has been overlooked in this discourse around the benefits or otherwise of fragmentation is that, depending on how the concept is applied, fragmentation could be 'managed' through overlapping spheres of political influence, as is the case with PMC and SCPC. Although the two local authorities are separate political and legal entities, they are linked by the provision of the Municipalities Act in law that means they share the same councilors (other than the mayor of PMC). Dual representation of this sort resides in a reform context in which norms of centralization are predominant and decentralization policies are implemented somewhat tentatively to ensure that existing power structures are not threatened. In an era of governmental change and reorganization, these issues of fragmentation vs consolidation in local government have taken centre stage alongside discussions on how to tackle problems arising from population dispersion and urban sprawl; the relationship between 'spillovers' and suburbanisation and ex-urbanisation; and local and regional economic development, among 
others. Reflecting these issues, a third perspective - the regionalists (see e.g. Nelson and Foster, 1999; Brenner, 1999; Lowery, 2000) - is also slowly gaining ground. The case for regionalism is mostly couched in socio-economic and ecological terms, as a way to combat urban inequalities. It complements the consolidationists by arguing that political fragmentation of metropolitan areas makes service provision, economic development and democratic voice difficult. Thus regional government is the solution, especially in dealing with the impact of globalization and the need to build new capacity to respond to global competition.

Differing views on the optimal size of local government units are inevitable as we seek the best means of assuring the functional integrity of local government while attending to its democratic genealogy. And of course, the differing contexts in which systems of local government operate, both socio-economic and political, is of fundamental importance in determining which body of ideas will prevail.

\section{A profile of Portmore}

The geographic space that is referred to as Portmore is in actuality an agglomeration of more than sixty distinct localities with a combined estimated population of 160,000. Each locality is very different in character ranging from the desirable residential neighbourhoods of Hellshire, inhabited by persons in the upper middle to high-income brackets, to the deprived areas of Portmore Lane and transitional areas like South Borough. Portmore has transformed from a group of dormitory-like localities that had their beginnings in government housing schemes of the late 1960s into a more balanced social and physical space evident in the integration of private housing developments and business districts. Rapid urbanization of Portmore occurred in the absence of a coordinated strategic long-term development plan and has led to an imbalance between urban expansion and adequate social infrastructure.

Located in the parish of St. Catherine, Portmore is in close proximity to two parish capitals, Spanish Town and Kingston, and is geographically contiguous to the port of Kingston, making it a site that experiences significant spillovers from the bustling commercial activities that characterise the two neighbouring urban centres. Portmore has a reasonably good network of roads, the most recent development being the controversial Highway 2000, a section of which passes through the area, as well as adequate water supply, electricity and telephone networks. At the height of its dormitory status, 
Portmore had the best educated workforce in the Caribbean, occupying an estimated $40 \%$ of all jobs in Kingston. This pattern of employment has been shifting with steady growth in economic investment and expansion of government services in Portmore itself.

Part of the justification given for directing the new six-lane Highway 2000 through Portmore towards Kingston was that it would be a conduit for economic expansion. Significant increases in revenue inflows into Portmore are expected to follow from the new highway with benefits from improved property values and expanded business opportunities accruing to residents in the short-run. Tourism is also identified as a potential source of revenue for the area on account of the existence of historical features such as the Taino sites, ${ }^{3}$ old plantations, Fort Augusta and Fort Clarence, that when combined with the general ecology of the area and the already popular beaches, have the hallmarks of a viable industry. The socio-economic profile of Portmore has been the sustaining force behind activism for local self-management. Residents were adamant that the area's resources and potential for economic take-off were compelling factors supporting their call to separate from the St. Catherine Parish Council. Moreover Portmore, more than any other group of localities in Jamaica, has an abundance of human resource capacity and capabilities that provide the foundation for local selfmanagement processes. Finally, the fact that the move for local self-management originated with the local citizenry provided an important signal of the high degree of community ownership of local decision-making, a critical benchmark of a viable local democracy.

\section{The process of municipalisation: Grassroots organizing and policy innovation}

Rapid development of housing in Portmore had been accompanied by increasing levels of residents' dissatisfaction with the quality of local services provided by the St. Catherine Parish Council. In particular, the erection of a set of townhouses known as Bridgeview during the early 1990s, on the last remaining viable 'green space' in the locality, precipitated a series of events one of which was a coalition of local interests into the Portmore Joint Citizens Association (PJCA). This marked a new phase in community activism for local self-management. The concept of a municipality became the platform on which the PJCA advocated for improved service provision and a greater community role in the management of these services. George Lee, who assumed leadership of the

\footnotetext{
${ }^{3}$ Arawak/Taino Indians inhabited Jamaica from 700-1600AD [Associate Editor note].
} 
PJCA in 1995, articulated these ideas in a concept paper that formed the basis of negotiations with the Ministry of Local Government, which since 1993 was itself overseeing a comprehensive programme of local government reform in Jamaica. In contra-position to George Lee's proposition for municipal status for Portmore, Arnold Bertram, then Minister of Local Government, introduced instead the concept of a 'city council' to form part of the St. Catherine Parish Council and which had responsibility for managing the affairs of Portmore. Minister Bertram's action was in effect a rejection of the PJCA's solution to the problems that Portmore faced, but his approach proved unsustainable, lasting for only six months, given the rejection of citizens' ideas. Minister Bertram's response to the PJCA had triggered an intense period of advocacy engendering an eddy of activities aimed at attaining the goal of municipal status.

In April 1994 Prime Minister P.J. Patterson established a Municipality Task Force with the mandate to study the political implications of transforming Portmore into a municipality and provide the requisite policy advice to the Ministry of Local Government. Later, disappointed by the lengthy deliberations and the inability of the Municipality Task Force to take concrete actions towards transforming Portmore, the Prime Minister prompted Minister Bertram to acquire the services of private consultancy to advise on the necessary steps to be taken in the creation of the Portmore Municipality within the current local government structure. Approximately two years later recommendations from the consultancy were that a two-stage implementation strategy should be followed which entailed in the first instance, creation of the Portmore Municipal Consultative Committee (PMCC), an interim body with legal status to coordinate local functions and preside over the formulation of a development plan for the area, as well as mobilize and manage finances. The PMCC operated through a Local Planning Secretariat (LPS) supported by five sub-committees - strategic planning, public relations and community development, finance, infrastructure and amenities, and environmental management. Subsequently, in December 1997, the Prime Minister announced that Portmore would be granted municipal status within a year, although this in fact took much longer.

Portmore's transformation to a political entity with decision-making authority was accompanied by a number of organizational changes, reflecting role transformation and concomitant shifts in political clout. The PJCA, which had apparently taken the municipal campaign as far as it could, was replaced by the Portmore Municipal 
Development Committee (PMDC), a broad-based organization that assumed responsibility for preparing a Framework Agreement for the Municipality (FAFM). Out of the FAFM emerged a Local Planning Authority (LPA) with a mandate to prepare an integrated development plan for Portmore. In August 2000 the LPA assumed the functions of Local Planning Secretariat paving the way for municipal status for Portmore. In March 2001 the St. Catherine Parish Council bestowed town status on Portmore and demarcated its geographic limits. Finally, in May 2003, the new Minister of Local Government, Portia Simpson-Miller, signed the Municipalities Act which granted municipal status to Portmore, fulfilling the second recommendation of the consultancy engaged by Minister Bertram.

\section{Local government reform}

As noted earlier, broader contemporary processes of local government provided an important context for developments in Portmore. The publication of Ministry Paper 8 of 1993 by the Ministry of Local Government had affirmed central government's commitment to the restoration of functions and responsibilities to local authorities, previously appropriated upwards to central government ministries and departments. Resolution of the perennial problem of creating independent sources of revenue for local service delivery was also placed on the agenda. Accordingly, the policy envisioned the transformation of local government to enable its participation in the development process, especially in light of significant socio-economic changes that were occurring in communities and towns. Increased urbanization with negative externalities, combined with increased citizens' demands for improved local service delivery, placed inordinate pressure on local administrative structures. Moreover, socio-economic interdependence between communities and townships had blurred jurisdictional boundaries, occasioning the concept of Development Areas, a social construct employed to distinguish between the parish, the traditional unit of local government, and new centres of economic activity that competed with parish capitals. In the meantime, new ideas about sub-national policy and international political developments such as the disintegration of the communist bloc were spurring interest in institutional arrangements reflecting the concept of governance.

The combination of incipient conditions for transforming local government in the domestic sphere, and the ideas that were now informing contemporary policy practice, provided the underpinning for Ministry Paper 7 of 2003, which promulgated a second phase of local government reform based on the ideological premises of public choice. 
Ministry Paper 7/03 assigned local government significant democratic value as seen in the overarching policy objective:

(T)he attainment of a strong and vibrant local government is essential to the attainment of a society in which all citizens enjoy real opportunities to fully and directly participate in and contribute to the management and development of local communities.

The paper saw local government reform and community development as complementary processes in the quest for citizen empowerment. It provided for the establishment of mechanisms to assure effective delivery of service to communities on a financially sustainable basis, and with the active involvement and participation of the citizens. While Ministry Paper 8 of 1993 was primarily concerned with administrative reshaping, more so than political restructuring, Ministry Paper 7/03, with its concentration on democratic renewal, implied a shifting of the balance of power in favour of the local level. In this regard democratic governance became synonymous with a functioning local government. Teune’s (1995: 9) view that “local governance has a built-in incentive for participation due to the immediacy of its actions and the ease of access of its workings compared to remote and complex national centres" captures the philosophical intent of the policy.

Thus grassroots advocacy for local self-management in Portmore and central government's design of local government reform policies were two distinct but parallel processes that coincided to create a 'window of opportunity' through which municipal status for Portmore was realized. This was a win-win game in that the residents of Portmore found the perfect niche to press their claim for government recognition of their capacity to manage their own affairs, while central government found an opportunity for experimentation with alternate forms of local decision-making. Both Ministry Papers 8 of 1993 and 7 of 2003 enunciated ideas that were consistent with the fundamental goal set by Portmore's campaigners for municipal status. The overarching goal of community empowerment set by the policy of local government reform resonated with locality-based action in Portmore, and provided leverage to change the local government structure.

\section{The philosophy and practice of local self-management}

The Municipalities Act of 2003 can be seen as deliberate policy action by central government to fragment the previous local government system in Jamaica. The Portmore Municipality not only changed the structure of local government but saw innovations at 
the sub-national level that exemplified experimentation in two aspects of local government policy: popular election of the Mayor, and construction of institutional arrangements for local/community self-management. The organizational structure and operational framework of the new municipality formalised the vision that the JPCA had for Portmore, and the Municipal Charter articulates a pattern of local governance structures aimed at achieving a more responsive, representative and accountable local authority indicated by four of the objectives:

(a) to provide for efficient and accountable management of the affairs of the Municipality of Portmore;

(b) to institute such measures as are necessary for ensuring that the management of the affairs of the Municipality are conducted in a manner which is responsive to the needs and views of the inhabitants of Portmore;

(c) to provide a governance mechanism which will enable the inhabitants of Portmore to -

(i) participate in determining the social services and regulatory frame work which will best satisfy their needs and expectations; and

(ii) verify whether public resources and authority are utilized or exercised, as the case may be, to their satisfaction;

(d) to promote social cohesiveness and a sense of civic duty and responsibility among all inhabitants and stakeholders in Portmore, which will facilitate collective action and commitment towards achieving the goal of a harmonious and stable community.

The Municipal Charter, granted by the Minister under the Municipalities Act, is the critical guidance instrument for efficient and effective functioning of PMC, and set the standard against which service provision within the municipality would be evaluated. Closer examination of the governance structure reveals interesting administrative and policy tendencies that characterize the process of giving effect to local self-management. Governance roles within the municipality are allocated among three institutional arrangements: (a) a decision-making, policy formulating, governing Municipal Council led by the Mayor and assisted by three full committees and four sub-committees; (b) an Advisory Council of representatives of civil society; and (c) a municipal office that is responsible to the PMC for the implementation of policy and administration of all the affairs of the municipality. These arrangements are now discussed. 


\section{Popularly elected mayor}

This represents one of the most revolutionary changes in Jamaica's local electoral processes as well as the broader political system, and is a calculated action employed to enhance local democracy. In the 2003 local government polls George Lee, former chairman of the JPCA, was elected mayor of the Portmore municipality and the country's first directly elected mayor. Being elected, there is a presumption that the mayor has adequate political/popular support which provides the requisite level of legitimacy to bring about changes to local policy formulation and implementation. It is also not an unreasonable expectation that George Lee's leadership of the grassroots movement that yielded municipal status for Portmore would accrue to him substantial amounts of political influence in local decision-making. Among Mayor Lee's responsibilities was the "building and maintenance of a strong alliance and effective working relationship between the Council and constituent communities to enable sustained local inputs into the policy process of the municipality" (Charter of the Municipality of Portmore). However, aside from the rhetoric of the democratic value, little administrative clout is attached to the position of directly elected mayor, who exercises only limited executive powers. Mayors may be further circumscribed by party discipline. For instance Mayor Lee was a vocal critic of government's approach to financing the municipality, but nevertheless had to exercise some restraint due to his political affiliation with the ruling People's National Party (PNP). Moreover, constant 'battles' between the PMC and central government for greater facilitation of the proper functioning of the municipality could have been construed by citizens as ineffective leadership and weak problemsolving skills. Also, Mayor Lee appeared to invest much time in dealing with challenges to the exercise of his authority which ultimately erode political capital and accountability to PMC constituents. Such internal conflicts stymied the design of a sustainable development plan for the municipality, to which the Canadian International Development Agency (CIDA) had committed both technical and financial resources.

As a prototype local authority, the PMC faced a number of other challenges in establishing sound governance structures and institutional frameworks. Mayor Lee admitted that for the duration of his tenure (2003-2007) the policy functions of the PMC were subsidiary to operational issues that seized the attention of local leadership (Interview May, 2009). PMC thus became concerned with minutiae during its formative years rather than investing in the synergies that created the social movement that led to its creation. 
This experience offers two crucial lessons. First, having a popularly elected mayor does not translate automatically into decentralized democratic governance. A popularly elected mayor is purely one step, albeit a major one, on the ladder of institutional arrangements that may appear mundane but which will create the policy and administrative ethos that will facilitate complete democratization. Second, decentralised democratic governance requires continuous efforts at both the local and central levels, and an investment of core resources, including time and threshold financing, to enable norms of local self-management to evolve and flourish. The PMC was at the stage of experimentation and when adequate support for key principals at the local level is crucial.

\section{The committee system}

The PMC "executes every power and duty of that parish council under any public or private act, in respect of the municipality to which the power or duty applied immediately before the coming into force of the Municipalities Act” (Municipalities Act [Portmore Order] 2003 section 4[13]). Thus its responsibilities are similar to those of other local authorities in Jamaica. Exceptions at the time of review were poor relief and welfare, the impounding and control of animals, and the provision of cemeteries and public health, which were retained as responsibilities of the St. Catherine Parish Council (SCPC). Also like other councils, PMC exercises its responsibilities through committees composed of councillors, who in most cases act as chairs, and a limited number of coopted members.

The presumed functional value of the committee system has not been questioned in the Portmore municipal experiment. PMC has a two-tiered committee structure comprising three full committees: Finance and Administration, Planning Development and Environment, and Infrastructure and Traffic Management; and four subcommittees: Disaster Preparedness and Public Health Management, Community Relations and Civic Affairs, Human Resources, and Contracts Allocation. These reflect the core service provision role of the municipality. Their operation and membership also reflects the raison d'être of the municipality - active engagement of the citizens through formal processes that facilitate their inputs into local decision-making. Indeed citizen involvement is axiomatic to the reinvigoration of local democracy and achievement of local development and prosperity. The constitution of both the full and sub-committees 
of the PMC reveals a high level of fidelity to these democratic values. Active community representation on committees was evident with the exception of three: Finance and Administration, Human Resources, and Contracts Allocation. The Community Relations and Civic Affairs Committee had the largest number of community representatives.

Nonetheless, one may deduce a conservative approach to participatory governance grounded in the belief that there ought to be limits on the extent to which citizens are privy to deliberations on policy issues such as finance, allocation of contracts, and human resource practices within the municipality. This conservatism can be seen as a residue of an administrative culture characterized by secrecy that pervades administrative practice at both local and national levels. A shift in administrative orientation has been observed, however, with the enactment of by-laws that authorize participation of citizens on committees that deal with planning and development. This appears to be a means of arresting growing disappointment with the absence of transparent policy processes in the PMC and inadequate involvement of citizens. However, the contentious area of contract allocation remains beyond public scrutiny, a poignant reminder of the political patronage still expected of local authorities.

\section{The advisory council}

If the level of influence that citizens have on municipal policy process falls below the level envisaged by the architects of the Portmore municipality, and if local community self-management norms are not sufficiently evident in PMC policy practice, then these institutional flaws must be placed at the feet of the Advisory Council. The Advisory Council is legitimated by the Municipalities Act 2003 but was not operationalised until January 2004 as a sort of policy ideas 'laboratory' for the municipality, fulfilling one criterion of the Municipal Charter and demonstrates a new approach to policy development and implementation at the sub-national level. Its membership comprises 17 members from civil society, private sector and community-based organizations. ${ }^{4}$ This broad base is strategic to the performance of its functions, four of which are to:

\footnotetext{
${ }^{4}$ Members are drawn from the Police, Portmore Joint Citizens Association, Greater Portmore/All Hellshire Citizens Association, Portmore Ministers Fraternal, Portmore Development Committee, small and large business operators, Chamber of Commerce, artisans, entertainers, attorneys, accountants, Social Development Commission (Youth), Portmore Junior Chamber and other service clubs, lay magistrates and medical professionals.
} 
(a) make recommendations in respect of the policies, programmes and plans of the Municipality, with the right to request the Municipal Council to reconsider such proposals;

(b) nominate persons to sit on committees of the Municipal Council;

(c) facilitate dialogue among sectors of the Portmore community in respect of issues that are pertinent to the advancement and proper governance of the Municipality, and make representations to the Municipal Council on such matters;

(d) be consulted in relation to the preparation and implementation of plans for the strategic and sustainable development of the Municipality.

The Advisory Council is an important institution situated at the centre of the policy formulation process of the municipality, designed to ensure that local governance is a product of viewpoints and initiatives from a wide range of local sources. However, the way it has functioned since coming into being appears at variance with the role it was assigned, and begs the question of whether members understood their role or were prepared to function in the capacity they were given. A review of attendance records revealed that members' attendance at meetings of the Advisory Council was sporadic (Minutes, February 21, 2005). The unsatisfactory attendance record of some members has been attributed to two issues. First is the involvement of the Advisory Council in the conflict over the Highway 2000 toll between the residents of the municipality and the government, which resulted in a clear division within the membership between two stances: those who sided with Portmore residents claiming that a toll violated their right to unobstructed passage to their homes; and those who thought that the toll was not a major problem since there was an alternate route. The conflict evolved a division along political party lines, and was seen by some to have diverted the Advisory Council from its mandate. It resulted in some members deciding not to attend meetings. Secondly, the late start of meetings of the Advisory Committee and sub-committees proved to be an inconvenience for some members who had other professional obligations to meet.

A further source of consternation for the PMC was the apparent ignorance of local policy issues displayed by some members, who relegated the deliberations of the Advisory Council to non-essential matters. Importantly, and contrary to the stipulations of the Municipal Charter, the Advisory Council failed to establish the Portmore Public Accounts Committee. This omission meant that the expenditure functions of the municipality were carried out without the benefit of close public scrutiny. A performance 
rating exercise conducted at a strategic planning retreat of the PMC in August 2004 had a majority of the assessors conceding that the Advisory Council was a weak organization that was incapacitated by the absence of by-laws to guide its operations, a budget to support research and evaluation, and a secretariat that would contribute to organisational cohesion. The below-par performance of the Advisory Council left the political and administrative leadership without an objective and independent source of policy advice. More important the Advisory Council did little to strengthen the link between the PMC and local communities.

\section{Financing in the context of dual representation}

Adequate and predictable sources of financing local government is an essential element of decentralization (Schoburgh 2006), and this makes fiscal reform a major development issue (Smoke 1993). This fact is not lost on local government modernization in Jamaica as financing is identified as a priority issue in reform policies and is correctly associated with capacity enhancement and achievement of autonomy at the local level. But despite this acknowledgement local government financing remains problematic and was no less so for the newly created PMC. Like the Parish Councils, the PMC is funded from four main sources: the parochial revenue fund (PRF), ${ }^{5}$ general revenues, ${ }^{6}$ self-financing services, ${ }^{7}$ and government grants. ${ }^{8}$ A statement appearing in The Gleaner of April 16, 2005 attributed to Mayor Lee (and corroborated in interviews conducted in April and May 2005 and April 2009), provides a clear picture of the financial state of the municipality:

\footnotetext{
${ }^{5}$ The Parochial Revenue Fund (PRF) includes revenues from property taxes and motor vehicle licenses. It is controlled and managed by a public officer designated by the Minister of Local Government. Disbursements from the PRF are as follows: each Parish Council receives $90 \%$ of the property tax paid in the relevant parish and $25 \%$ of the amount paid for motor vehicle licence fees. The remaining $10 \%$ of the property tax is distributed to each parish on the basis of need. The remaining $75 \%$ of the motor vehicle licence fees is disbursed to each Parish Council on the basis of the number of miles of parochial roads in the parish expressed as a percentage of the total number of miles of parochial roads in the island. Disbursements from the PRF are used to finance road maintenance and property related services such as solid waste management, street lighting and beautification.

${ }^{6}$ General revenue is made up of user fees and municipal charges. It includes items such as: trade licenses; barber and hairdresser licences; places of amusement licences; advertisements and billboards; and building and sub-division fees.

${ }^{7}$ Self-Financing services consist of income generating enterprises run by the PMC. At the time of the review, the only commercial service entity within the portfolio of the municipality was the market.

${ }^{8}$ Government Grants are given to PMC to assist with administrative costs .
} 


\begin{abstract}
... the biggest challenge that faces the Municipal Council is the lack of financial support from central government and the lack of autonomy...the problems posed by the shortfall in financial support from the government were made worse by the unpredictability of the revenue flow from the government...it is difficult to make programmed expenditure when one is not sure whether approved estimates and other promises will be honoured. If we had not run a tight ship we would have sunk...the expectations of the citizens far outstrip the capacity of the Municipal Council, since the Council is not well-equipped due to severe budget constraints to perform the wide range of functions that some citizens demand.

(The Gleaner, April 16, 2005)
\end{abstract}

What is striking is that a newly established local authority has from its inception operated under conditions of significant revenue shortfall arising from two factors: (a) central government's failure to provide $\$ 30$ million it committed to aid start-up processes; and (b) the organizational and institutional complexities inherent in dual representation which emerged with the establishment of the PMC within the parish of St. Catherine. In the first year of operation of the PMC, the SCPC retained functional as well as legal authority for provision of certain services within the municipality - poor relief and welfare, impounding and control of animals, provision of cemeteries, and public health. The collection of property tax within the municipality was also a latent source of conflict between the two authorities as SCPC retained administrative control for this function, and was concerned about the implications of establishing PMC for the revenue base of the parish in general (The Gleaner, September 2003). The population profile and density of Portmore represents a resource that has a decisive role in whether either local authority remains economically viable. Moreover, the revenue base of the new municipality is subject to a complex array of decision points - SCPC, Ministry of Local Government, Ministry of Finance and the PMC itself - with a degree of institutional complexity that may have been under-estimated at the start of the process of municipalisation.

Apart from the complications associated with financing the municipality, dual representation presents particular challenges for the councillors' role in steering local self-management processes. As noted earlier, PMC councillors are also full members of the SCPC with all legal entitlements intact, and they exercise their voting rights as well as chair committees within the SCPC. Attending and participating in meetings of both local authorities increased their representational load substantially, reducing their ability to provide effective political representation within PMC.

Dual representation together with the contentious issue of revenue generation and allocation has made the relationship between the PMC and SCPC tenuous, at best. What 
does this mean for the future? Is it possible for the municipality to achieve a greater level of independence in its operations without these tensions? It seems unlikely as fragmentation is inherently conflictual and some level of tension in organizational interactions should be anticipated. Biehl's (1998) ideas on municipalism appear relevant here: "existing power structure will hardly tolerate the existence of a confederation of democratized municipalities that has created a democratic politics, an empowered citizenry, and a municipalised economy.”

\section{Lessons in theory and praxis}

Democratized decentralized governance represents the fundamental goal of PMC and is evident to varying degrees in the politico-administrative practices of the local authority. The PMC's approach to the conduct of general meetings; facilitation of direct presentations from the public to the Council; public screening of the proceedings of meetings via local community cable channels; and employment of 'town hall' meetings to solicit citizens' inputs and recommendations are elemental to a democratic ethos and demonstrate deliberate efforts on the part of the PMC's political and administrative leadership to transform the way business is conducted at the local government level.

Steady progress has been made towards realization of the objective of citizens taking responsibility for managing their own affairs through partnership arrangements that have been employed in local activities such as development of community parks and implementation of beautification projects within the municipality. Community selfmanagement norms have featured in development of an environmental program dubbed 'the Greening of Portmore', as well as in the design of a zone system for disaster preparedness and emergency management services. Significant levels of voluntary cooperation are also apparent in the efforts of the local citizens' association in the Four East Area to monitor implementation of specific PMC projects.

However, these positive trends in the transformation of local governance processes have not taken root within the organizational structures, which still follow a traditional local authority model with typical 'machine bureaucratic' values and mechanistic approaches, plus their dominance by elected representatives. The constitution of the committees and sub-committees of the PMC has indicated, for the most part, a tilting of the decision balance towards the community, principally to capture the naturally occurring activism that characterizes Portmore's constituent communities and to leverage community 
resources. But this shift has not been sufficiently radical to counter the norms associated with the dominance of the political sphere. The fact that community participation was most significant on the Community Relations and Civic Affairs Committee suggests reinforcement of a culture of 'immediacy' in community participation and the relegation of community interests to dealing with short-term objectives.

The disjuncture between the rhetoric of community/local self-management and the modest outcomes of the Municipalities Act 2003 must be understood against the background of the value conflicts that emerge in local government reform and organizational change. This is not unique to local government modernization in Jamaica. For example, reform in the United Kingdom under New Labour provides important lessons about the tensions and associated disjuncture that exist between the need to retain central performance control but at the same time respond to the local aspirations and differences (Painter and Clarence 2000; Painter, Isaac-Henry and McAnulla 2003;Martin and Boaz 2000). For these reasons Newman (2001) reminds reformers of the folly in adopting a single governance narrative. According to Painter, Isaac-Henry and McNulla (2003: 37) the notion of 'citizen-centred governance' demands that "the ethos of customer service, if more than cosmetic, must also become a driver for deeper changes in the way a council is run, with ramifications throughout the organization.” On this basis, the philosophy that undergirds the Portmore municipality appears antithetical to the compartmentalized decision structures associated with the current arrangements for service provision and committees. Local self-management norms are appropriately associated with the promotion of coordination and possibly a more corporate focus. However, such new structural and administrative forms place greater demands on political and administrative leadership, requiring new skills and competencies, and challenge traditional organisational culture and policy outlook.

If the committee system upholds traditional administrative values, then the Advisory Council is the institutional arrangement devised to neutralize the influence of these values and represents an important innovation of the Municipalities Act 2003. However, the Advisory Council has faltered, having yet to achieve the level of political clout that would permit it to establish its presence as an authentic local policy advisory mechanism and stamp its authority on its portfolio responsibilities. Three inter-related explanations are offered for this outcome. Firstly, the difference and tensions between the goals and processes of social development and political power. Secondly, inadequate preparation of 
the members of the Advisory Committee in terms of their roles and clarification of the boundaries and interactions between the civil and political spheres. Thirdly, resistance to change on the part of elected councilors. This point was highlighted by Mayor Lee who stated that:

It was a battle for councillors to accept the Advisory Council as they saw it as an intrusion...They raised concerns about the confidentiality principle being breached...Today the Advisory Council does not have a vote on the Finance and Administration Committee (Interview April 2009).

The functional deficiencies of the Advisory Council robbed it of political capital. Moreover, reformers erred in believing that the professional capacities and service orientation of the membership of the Advisory Council were sufficient grounds to expect that the PMC would have access to both policy expertise and policy information, and that the Council's membership would transcend partisan interests. Again George Lee's assessment of the Advisory Council is telling: "The Advisory Council was not strong enough to take on the council...its constitution did not allow for direct community representation...they were more inclined to maintain the status quo" (Interview April 2009). The Advisory Council was the institutional response to the conviction that public participation in local government should be enhanced, but its efficacy depended on factors that were not taken into account and which hindered community influence on municipal politics.

Finally, a comment on the notion of popularly elected mayor, which arguably represents the most radical aspect of the municipal experiment in Jamaica, and like the Advisory Council represents a counterpoint to the traditional committee system. Popularly elected mayors have increasingly become a feature of sub-national politics in, for example, Western Europe as a means of improving management of local affairs and providing effective representation of the local community (Fenwick and Elcock 2005). It is theorized that a popularly elected mayor has the potential to: (a) raise the profile of local elected representatives; (b) redress the asymmetry in power between central and local levels; (c) re-invigorate local democracy; (d) build local/community leadership capacity; (e) reinforce internal organizational leadership; and (f) reduce the impact of party politics on local policy (Fenwick and Elcock 2005:62; Clark et al 1996). These values are relevant in the case of the Portmore experiment, as a determination was made that a popularly elected mayor is a worthwhile and workable option in the empowerment strategy that underscores local government reform in Jamaica. However, implementation 
of the concept has highlighted some important lessons, particularly about the way in which politics conditions the relationship between management and political leadership at the local and central levels; the evident threats to organisational and individual power bases; the need for a supportive organizational framework; and the need for complementary reorientation of their political, administrative and policy outlook on the part of other locally elected representatives as well as communities. George Lee had this to say about his tenure as mayor:

In theory the office of elected mayor isolates you from direct politics/party influence as your power and authority came from the people and were supported in law. I was conscious of my authority and this brought me into conflict with my PNP counterparts...it (directly elected mayor) was good for community...bad for politics (Interview April 2009).

The fact that George Lee, even with his close connection to the grassroots movement that pre-dated the municipality, was unsuccessful in his bid to retain the position of mayor in the municipal elections of 2007 may be seen as one of the enduring lessons of the Portmore experiment. His successor, Keith Hinds, has strong political support both at the local level with a majority council, and at the national level where his affiliated JLP has won government and is seeking to advance the process of local government reform in preparation for full decentralization of authority to the local level. Political and administrative shifts create new dynamics that can overcome the inertia that sometimes afflicts protracted reform movements. For it is now possible for Mayor Hinds and the new Minister of State for Local Government to change the fortunes of the PMC.

\section{Conclusion}

The Portmore experiment has demonstrated quite unequivocally that municipalism can be a viable option in local government organization in Jamaica. The PMC adopted an approach to local governance which has in some respects at least enabled communities to take more responsibility for the management of their affairs. Service delivery has attained fairly high standards despite the challenge of financing. Moreover, the initiatives taken to augment financial inflows into the municipality, along with the collaborative arrangements that have been attempted, signify a willingness to chart a new direction in local governance in Jamaica. Nonetheless, this review shows that more widespread application of the municipalisation process requires attention to a number of key factors 
if the next phase of implementation is to be less traumatic for local leadership and constituent communities:

- Administration: The protracted delay in providing the PMC with a dedicated secretariat and the difficulties experienced in staffing the Municipal Office must be corrected in order to avoid the impression that political expediency and gamesmanship, rather than a genuine concern for socio-political transformation and local government modernization are driving the empowerment strategy of local government reform.

- Viability: Adequate provisions must be made for the financing of the municipality. However, the Portmore experiment has shown that it is unwise to rely upon central government financial support as a means of achieving viability, and that local government must seek alternative sources of funding and in particular must reorient its functions towards an economic developmental role.

- Policy Focus: The idea of an Advisory Council is progressive and suggests a new orientation in local policy development. The Portmore experience illustrates, however, that how to successfully implement such a concept has to be clearly understood, and its successful adoption elsewhere depends on requisite material and human resources to enable it to fulfil its mandate.

- Dual representation: Dual representation has the potential to deflect attention from the core goals of the municipality if not regulated properly. Given its direct impact on the quality of local representation it is a matter that requires swift resolution.

\section{References:}

Biehl, J. 1998, The Politics of Social Ecology, Black Rose Books Ltd: London.

Boyne, G. A. 1996, 'Competition and Local Government: A Public Choice Perspective’, Urban Studies, vol. 33, no. 4-5, pp. 703-721.

Brenner, N. 1999, 'Globalisation as Reterritorialisation: The Rescaling of Urban Governance in the European Union', Urban Studies, vol. 369, no. 3, pp. 431-451.

Clarke, M., Davis, H., Hall, D. and Stewart, J. 1996, Executive Mayors for Britain? New Forms of Political Leadership Reviewed, School of Public Policy, University of Birmingham: Birmingham.

Commonwealth Local Government Forum (CLGF) 2009, Commonwealth Local Government Handbook, Commonwealth Local Government Forum.

Dahl, R. 1967, 'The City in the Future of Democracy', American Political Science Review, vol. 61, no. 4, pp. 953-70.

Fenwick, J. and Elcock, H. 2005, 'New Development: The Elected Mayor and 
Local Leadership', Public Money and Management, vol. 25, no. 1, pp. 61-66.

Government of Jamaica 2005, Minutes of Meeting of the Portmore Citizen's Advisory Council, Portmore Citizen's Advisory Council, 21 February.

Government of Jamaica 2005, Minutes of the Contracts Allocation Committee of the Portmore Municipal Council, Allocation Committee of the Portmore Municipal Council, 7 February.

Government of Jamaica, Municipalities Act 2003 (Jamaica).

Government of Jamaica, Municipalities Act 2003 (Jamaica), Charter of the Municipality of Portmore, 22 May.

Gunlicks, A. B. 1981, Local Government Reform and Reorganization: AnInternational Perspective, Kennikat Press: London.

Hill, R. C. 1974, 'Separated and Unequal: Government Inequality in the Metropolis', American Political Science Review, vol. 68, no. 4, pp. 1557-1568.

Hinds, A. 2005. Interview with Lee, G. (Mayor of Portmore Municipality, Jamaica), 13 April and 12 May. [unpublished source]

Jamaican Ministry of Local Government 1993, Ministry Paper 8 of 1993.

Jamaican Ministry of Local Government 2003, Ministry Paper 7 of 2003.

Jamaica Observer 2005, 30 January.

King, D. and Stoker, G. 1996, Rethinking Local Democracy, MacMillan Press Ltd: Houndmills.

Kjellberg, F. 1995, 'The Changing Values of Local Government', ANNALS, AAPSS 540, pp. 40-50.

Lee, G. (n.d.), The Making of a Municipality, Concept Paper written in the capacity of Chairman of the JPCA. [unpublished source]

Leemans, A. F. 1970, Changing Patterns of Local Government. International Union of Local Authorities: The Hague.

Lowery, D. (n.d.). 'Metropolitan Governance Structures from a Neoprogressive Perspective' (unpublished version), viewed April 4, 2009

$<$ http://localgov.fsu.edu/readings_papers/form\%20of\%20govt/Lowery_Metropolitan_Gove rnance.doc $>$

Lowery, D. 1999a, 'Answering the Public Choice Challenge to Progressive

Reform Institutions: A Neoprogressive Research Agenda', Governance, vol. 12, no. 1, pp. 29-56.

Lowery, D. (1999b). 'Sorting in the Fragmented Metropolis: Updating the Social

Stratification-Government Inequality Debate', Public Management, vol. 1, no. 1, pp. 7-26.

Lowery, D. (2000). 'A Transactions Costs Model of Metropolitan Governance:

Allocation versus Redistribution in Urban America', Journal of Public

Administration Research and Theory, vol. 10, no. 1, pp. 49-78.

Madison, J. 1941, The Federalist, Random House: New York.

Magnusson, W. 1986, 'Bourgeois Theories of Local Government', Political Studies, vol. 34, pp. $1-18$.

Martin, S. and Boaz, A. 2000, 'Public Participation and Citizen-Centred Local Government', Public Money \& Management, vol. 20, no. 2, pp. 47-53.

Neiman, M. 1976, 'Social Stratification and Government Inequality', American

Political Science Review, vol. 53, no. 4, pp. 474-493.

Nelson, A. and Foster, K. 1999, 'Metropolitan Governance Structure and 
Income Growth', Journal of Urban Affairs, vol. 21, no. 3, pp. 309-324.

Newton, K. 2006, 'Is Small Really So Beautiful? Is Big Really So Ugly? Size, Effectiveness, and Democracy in Local Government', Political Studies, vol. 30, no. 2, pp. 190-206.

Painter, Chris, Isaac-Henry, K. and McAnulla, S. 2003, 'Modernising Local

Government: Micro-Organisational Reform and changing Local Structural

Configurations’, Local Government Studies, vol. 29, no. 4, pp. 31-53.

Painter, C. and Clarence, E. 2000, 'New Labour and Inter-Governmental Management: Innovation and Modernisation', Public Money \& Management, vol. 2, no. 4, pp. 477478.

Portmore Municipal Council 2004, Report of the Strategic Planning Retreat of the Portmore Municipal Council, Portmore Municipal Council.

Rose, D. 2003, 'Portmore Residents Anticipating Implementation Phase of Municipality', Jamaica Information Service, 27 March.

Schoburgh, E. D. 2006, Local Government Reform, The Prospects for Community Empowerment in Jamaica, SALISES: Mona, Kingston.

Schoburgh, E. D. 2007, 'Local Government Reform in Jamaica and Trinidad: A Policy Dilemma.', Public Administration and Development, vol. 27, pp. 159-174.

Schoburgh, E. D. 2009, 'Paradigm Shift or Rhetorical Flourish? The "New Orthodoxy” of Local Governance in the Caribbean', Social and Economic Studies, vol. 58, no. 1, pp. 95-124.

Schoburgh, E. D. 2009. Interview with Lee, G. (Former Mayor of Portmore Municipality, Jamaica), 16-23 April. [unpublished source]

Sharpe, L. J. 1970, 'Theories and Values of Local Government', Political Studies, vol. 18, no. 2, pp. 153-174.

Smith, B. C. 1998, 'Local government and the transition to democracy: A review

Article', Public Administration and Development, vol. 18, pp. 85-92.

Tiebout, C. M. 1956, 'A Pure Theory of Local Expenditures', The Journal of

Political Economy, vol. 64, no. 1, pp. 416-424.

Teune, H. 1995, 'Preface to the Annals', AAPSS 546, pp. 8-10.

The Gleaner, 10 September 2003; 8 August 2004; 16 April 2005. 